\title{
Analisa Perbandingan Perhitungan Geser Lentur Berdasarkan Truss Model
}

\author{
M. Sigit Darmawan \\ Dosen D3 Teknik Sipil FTSP-ITS \\ email: msdarmawan@ce.its.ac.id
}

\begin{abstract}
ABSTRAK
Sebagian besar para peneliti geser pada beton bertulang telah setuju bahwa teori Truss Model merupakan cara yang meyakinkan untuk menganalisa geser. Akan tetapi hingga kini, belum ada kesepakatan mengenai Truss Model versi mana yang paling mendekati mekanisme geser. Studi ini bertujuan untuk mengetahui perbedaan yang terdapat pada Truss Model usulan Nielsen, Hardjasaputra, Reineck dan Collins dkk untuk perhitungan geser lentur. Perumusan Truss Model ini juga akan dibandingkan dengan perumusan geser yang dipakai oleh SNI 03-2847, AS 3600 dan EC2. Hasil studi menunjukkan bahwa keempat Truss Model diatas hanya berlaku untuk balok dengan jumlah tertentu tulangan geser $\left(\mathrm{q}_{\mathrm{v}}\right)$. Truss Model usulan Reineck berlaku untuk balok dengan $\mathrm{q}_{\mathrm{v}} \leq \mathrm{q}_{\mathrm{vmin}}$, Hardjasaputra dan Collins dkk berlaku untuk balok dengan $\mathrm{q}_{\mathrm{v}} \geq \mathrm{q}_{\mathrm{vmin}}$, dan Nielsen hanya berlaku untuk balok dengan $\mathrm{q}_{\mathrm{v}}=\mathrm{q}_{\mathrm{vmax}}$. Hal ini terjadi karena kriteria keruntuhan geser berubah dengan bertambahnya jumlah tulangan geser. Studi ini juga menunjukkan bahwa Truss Model usulan Collins dkk adalah yang paling mendekati hasil tes yang didapat dari survey literatur, sedangkan dari hasil uji beban ketiga Truss Model (selain Nielsen) menghasilkan prediksi rata-rata hanya $\pm 60 \%$ dari beban runtuh. Hasil prediksi tersebut masih lebih rendah dibandingkan dengan prediksi berdasarkan ketiga peraturan beton diatas
\end{abstract}

Kata kunci: truss model, tulangan geser, beton bertulang

\section{PENDAHULUAN}

Pada saat ini perhitungan geser lentur yang terdapat pada hampir semua peraturan beton lebih banyak memakai perumusan yang diturunkan secara empiris. Perumusan empiris yang digunakan oleh masing-masing peraturan beton berbeda antara satu dengan yang lainnya. Sebagai akibatnya timbul ketidak-seragaman dalam perhitungan geser lentur. Sebaliknya untuk perhitungan momen lentur pendekatan yang dipakai oleh semua peraturan beton relatif sama, yaitu dengan pendekatan teoritis (model) yang diturunkan dari prinsip keseimbangan gaya dan kompatibilitas regangan.

Pada umumnya ada dua macam pendekatan yang dapat diambil dalam menurunkan sebuah perumusan, yaitu pendekatan empiris dan teoritis (model). Meskipun perumusan empiris telah menghasilkan perhitungan geser lentur yang aman dan konservatif (Somo dan Hong, 2006), pendekatan berdasarkan model lebih disukai (von Ramin dan Matamoros, 2006) karena mempunyai beberapa kelebihan, antara lain:
- aliran dari beban (load-path) menjadi lebih jelas sehingga perencana struktur tidak hanya sekedar memasukkan angka kedalam rumus yang ada

- lebih bersifat umum (general) dan tidak memerlukan percobaan yang terlalu banyak untuk membuktikan keabsahannya

- pada umumnya lebih hemat

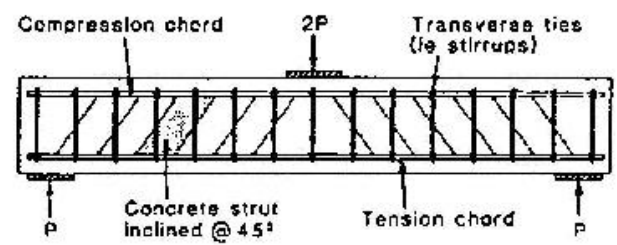

Gambar 1. Truss Model untuk Perhitungan Geser Lentur

Untuk perhitungan geser lentur para ahli struktur beton telah sepakat bahwa perumusan yang diturunkan dari Truss Model dapat dipakai sebagai alternatif, selain memakai perumusan empiris. Dalam Truss Model (seperti terlihat pada Gambar 1) penampang beton dimodelkan sebagai sebuah sistim rangka batang, dimana tulangan yang ada dimodelkan sebagai batang tarik sementara beton yang 
menerima tekan dimodelkan sebagai batang tekan. Namun demikian hingga saat ini belum dicapai kesepakatan mengenai Truss Model versi mana yang dipakai untuk perhitungan geser lentur.

Pada studi ini, Truss Model yang akan dijadikan obyek penelitian adalah Truss Model usulan dari Nielsen (1978), Hardjasaputra (1987), Reineck (1991) serta Collins dkk (1996). Pemilihan Truss Model ini juga untuk menunjukkan bagaimana perubahan (evolusi) yang terjadi pada anggapan yang dipakai pada masing-masing Truss Model diatas, yang sekaligus mencerminkan perkembangan penelitian mengenai geser yang telah dilakukan selama beberapa dekade. Perlu diketahui bahwa Truss Model usulan Collins dkk (Modified Compression Field Theory) ini telah diadopsi oleh Canadian Standard dan AASHTO LRFD specifications sejak tahun 1994.

Tujuan utama dari penelitian ini adalah :

- membandingkan keempat Truss Model satu dengan yang lainnya, dengan datadata percobaan yang diperoleh dari literatur dan hasil percobaan pembebanan, serta dengan perhitungan geser lentur berdasarkan SNI 03-2847, AS 3600 dan Eurocode 2

- merekomendasikan salah satu Truss Model sebagai alternatif perhitungan geser selain memakai perumusan empiris yang telah ada dalam SNI 03-2847

Perlu disampaikan disini bahwa perumusan geser yang ada dalam SNI 03-2847 berasal dari perumusan yang dipakai oleh $\mathrm{ACl}$ 3181999.

Pada penelitian ini dipakai batasan sebagai berikut :

- balok beton bertulang yang diteliti adalah balok langsing dengan beban lentur saja dan bersifat monotonik

- untuk keperluan perbandingan, semua faktor keamanan (faktor reduksi penampang dan faktor beban) diambil sama dengan 1,0

\section{PERUMUSAN TRUSS MODEL}

\subsection{Nielsen}

Truss Model usulan Nielsen (1978) diturunkan berdasarkan teori plastisitas, dimana stress field yang terjadi pada penampang beton akan mengimbangi beban luar. Sedangkan formulasi kekuatan geser nominal penampang, $V_{n}$ adalah sebagai berikut:

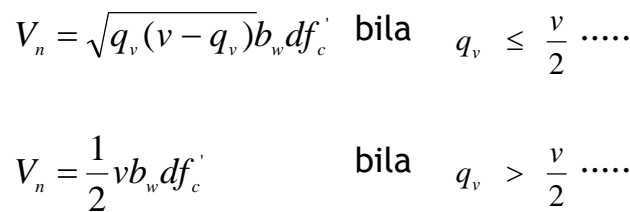

dengan $\quad q_{v}=\frac{A_{v} f_{y}}{b_{w} \cdot s \cdot f_{c}^{\prime}}$ dan $v=0.7-\frac{f_{c}^{\prime}}{200}$

$A_{v}, f_{y}$ dan $s$ adalah luas penampang, tegangan leleh dan jarak tulangan geser, $f_{c}$ ' adalah mutu beton, $b_{w}$ dan $d$ adalah lebar dan tinggi efektif balok.

Adapun besarnya sudut batang tekan $\theta$ adalah

$$
\cot \theta=\sqrt{\frac{v}{q_{v}}-1} \leq 2,5
$$

\subsection{Hardjasaputra}

Asumsi yang dipakai oleh Nielsen (1978) dan Collins dkk (1996) dalam menurunkan perumusan Truss Model adalah sudut batang tekan sejajar dengan sudut retak. Sebaliknya Hardjasaputra (1987) memakai anggapan sudut batang tekan tidak sejajar dengan retak yang terjadi. Hal ini berarti ada transfer gaya melintasi retak berupa gaya gesekan (biasa disebut $\mathrm{V}_{c}$ ). Namun demikian Hardjasaputra tidak memperhitungkan besarnya gaya gesekan tersebut secara eksplisit (tidak memisahkan nilai antara $V_{c}$ dan $V_{s}$ ). Adapun formulasi kekuatan geser nominal penampang, $V_{n}$ adalah sebagai berikut:

$$
\begin{aligned}
V_{n} & =q_{v} \cdot b_{w} d f_{c}^{\prime} \cot \theta, \ldots \ldots \\
& =b_{w} \cdot d \sin \theta \cos \theta \sigma_{d s}
\end{aligned}
$$

dimana $\sigma_{d s}$ adalah tegangan yang terjadi pada batang tekan. Untuk menentukan kuat geser nominal $V_{n}$, berdasarkan model ini harus dilakukan perhitungan dengan cara iteratif sampai kondisi kinematis berdasarkan persamaan (6) dapat dipenuhi. 


$$
\tan \left(\beta_{r}-\theta\right)=\frac{\Delta s / a_{c r}}{\Delta n / a_{c r}}
$$

dimana $\Delta n$ adalah perpindahan retak tegak lurus sumbu retak, $\Delta s$ perpindahan retak sejajar sumbu retak, $a_{c r}$ adalah jarak retak diukur tegak lurus sumbu retak dan $\beta_{c r}$ adalah sudut retak. $\Delta n$ dan $\Delta s$ tergantung pada nilai regangan tulangan tarik, regangan tulangan geser dan regangan batang tekan.

\subsection{Reineck}

Reineck (1990) mengusulkan Truss Model dengan asumsi sudut batang tekan lebih kecil dari sudut retak seperti halnya Hardjasaputra. Dengan asumsi ini berarti ada transfer gaya melintasi retak berupa gaya gesekan/aggregat interlock action (biasa disebut $V_{c}$ ). Dengan memakai model tersebut serta dengan menganggap bahwa retak adalah lurus dan membuka dengan arah tegak lurus sumbu retak, Reineck menurunkan formulasi untuk deformasi badan balok. Berdasarkan anggapan tersebut, sudut batang tekan dapat ditentukan dengan cara iteratif. Adapun perumusan kekuatan gesernya adalah sebagai berikut :

$$
V=V_{c}+V_{s}=V_{c}+\frac{A_{v}}{s} f_{y} \cdot z \cdot \cot \beta_{c r}
$$

dimana $\mathbf{z}$ jarak antara gaya tarik pada tulangan bawah dengan gaya tekan pada daerah tekan. Sedangkan $V_{c}$ dapat dihitung dari perumusan dibawah ini:
$V_{f}=b_{w} z \cdot\left[\tau_{f 0}+\tau_{f \sigma}\left(1-\cot \beta_{c r} / \mu_{f}\right)\right]$

dimana $\tau_{f 0}$ adalah komponen gaya geser yang diperhitungkan tanpa gaya normal pada retak, $\tau_{f \sigma}$ komponen gaya geser yang diperhitungkan dengan gaya normal pada retak dan $\mu_{f}$ adalah koefisien gesek yang harganya diambil sebesar 1,7.

\subsection{Collins dkk.}

Collins dkk (1996) mengusulkan Truss Model yang didasarkan pada prinsip keseimbangan dan kompatibilitas regangan. Kekuatan geser yang timbul, ditentukan dengan memakai hubungan tegangan-regangan yang bersesuaian untuk baja tulangan dan beton dalam kondisi retak diagonal. Adapun formulasi dari teori ini adalah sebagai berikut:

$$
\begin{aligned}
V_{n} & =V_{c}+V_{s} \\
& =\beta \sqrt{f^{\prime}{ }_{c}} b_{w} j d+\frac{A_{v} f_{y} z \cot \theta}{s}
\end{aligned}
$$

dimana $V_{c}$ adalah kekuatan geser yang diberikan oleh tegangan tarik sisa pada beton yang dalam keadaan retak dan $V_{s}$ adalah kekuatan geser yang diberikan oleh tegangan tarik pada tulangan geser. Sedangkan $\beta$ adalah sebuah faktor yang tergantung pada lebar retak, ukuran agregat maksimum, jarak rata-rata retak diagonal dan regangan tarik utama pada penampang beton dalam kondisi retak.

Tabel 1. Perumusan Kuat Geser Nominal Beton $\left(\mathbf{V}_{c}\right) \&$ Kuat Geser Nominal Tulangan $\left(\mathbf{V}_{s}\right)$

\begin{tabular}{|c|l|l|}
\hline Standar Beton & \multicolumn{1}{|c|}{$\mathbf{V}_{\mathbf{c}}$} & \multicolumn{1}{|c|}{$\mathbf{V}_{\mathbf{s}}$} \\
\hline \hline $\begin{array}{c}\text { AS 3600 } \\
\text { Pasal 8.2 }\end{array}$ & $V_{c}=\beta_{1} b_{w} d \cdot \sqrt[3]{\frac{A_{s}}{b_{w} d} f_{c}^{\prime}}$ & $V_{s}=\frac{A_{v} f_{y} d \cot \theta}{s}$ \\
\hline $\begin{array}{l}\text { Eurocode 2 } \\
\text { Pasal 4.3.2 }\end{array}$ & $V_{c}=0,0525\left(f_{c}^{\prime}\right)^{\frac{2}{3}} k(1,2+40 \rho) b_{w} d$ & $V_{s}=\frac{A_{v} f_{y} 0.9 d \cot \theta}{s}$ (General Method) \\
\hline $\begin{array}{c}\text { SNI 03-2847 } \\
\text { Pasal 13.3 }\end{array}$ & $V_{c}=\frac{1}{7}\left[\sqrt{f_{c}^{\prime}}+\left(120 \rho V_{u} d / M_{u}\right)\right]$ atau & $V_{s} f_{y} 0.9 d$ \\
& $V_{c}=\frac{1}{6} \sqrt{f_{c}^{\prime}} b_{w} d$ & \\
\hline
\end{tabular}


Tabel 2. Kriteria Keruntuhan untuk Truss Model

\begin{tabular}{|l|l|}
\hline \multicolumn{1}{|c|}{ Truss Model } & \multicolumn{1}{c|}{ Kriteria Keruntuhan } \\
\hline \hline Nielsen & tulangan geser meleleh bersamaan batang tekan runtuh \\
\hline Hardjasaputra & besarnya regangan tulangan geser \\
\hline Reineck & gaya gesekan (friction) mencapai kondisi batas \\
\hline Collins dkk & tulangan geser meleleh sebelum batang tekan runtuh \\
\hline
\end{tabular}

Tabel 3. Data Masukan untuk Truss Model

\begin{tabular}{|l|l|}
\hline \multicolumn{1}{|c|}{ Truss Model } & \multicolumn{1}{c|}{ Data Masukan } \\
\hline \hline Nielsen & sudut batang tekan $(\cot \theta \leq 2,5)$ \\
\hline Hardjasaputra & besarnya regangan tulangan geser dan sudut retak \\
\hline Reineck & sudut retak \\
\hline Collins dkk. & jarak retak \\
\hline
\end{tabular}

\subsection{Perumusan Geser Berdasarkan SNI 03- 2847, AS 3600 \& Eurocode 2}

Sebagai pembanding untuk perumusan geser berdasarkan Truss Model, pada Tabel 1 disajikan perumusan geser berdasarkan SNI 03-2847, AS 3600 dan Eurocode 2. Kuat geser nominal total adalah jumlah dari kuat geser nominal beton dan tulangan.

Dari tinjauan pustaka yang telah dilakukan diperoleh perbedaan yang cukup besar antara Truss Model yang satu dengan yang lainnya. Nielsen serta Collins dkk memakai asumsi batang tekan sejajar dengan arah retak, sementara Hardjasaputra dan Reineck beranggapan sudut batang tekan tidak sejajar (lebih kecil) dengan arah retak. Perbedaan mendasar lainnya adalah kriteria keruntuhan geser yang dipakai oleh masingmasing perumus Truss Model seperti terlihat pada Tabel 2. Adanya perbedaan asumsi tersebut serta kriteria keruntuhan yang dipakai, dengan sendirinya akan menimbulkan perbedaan prediksi kekuatan geser.

Dari tinjauan pustaka diketahui pula bahwa keempat Truss Model masih memerlukan data yang harus ditentukan dari percobaan seperti disajikan pada Tabel 3. Hal ini tentu saja membuka peluang bagi perumus Truss Model untuk menyesuaikan prediksi kekuatan gesernya dengan hasil percobaan. Adanya data masukan ini menjadi titik lemah dari Truss Model yang bersangkutan, meskipun secara fisik model ini mampu memberikan gambaran yang lebih jelas tentang mekanisme geser dibandingkan perumusan empiris.

\section{METODOLOGI PENELITIAN}

Untuk mencapai tujuan penelitian dilakukan dengan 2 (dua) cara, yaitu membandingkan prediksi berdasarkan Truss Model dengan

- hasil tes geser yang ada dalam literatur

- hasil tes pembebanan (eksperimen)

Eksperimen dilakukan untuk memperoleh hasil yang cukup obyektif dan tidak sematamata tergantung pada hasil percobaan terdahulu, serta untuk melihat apakah kriteria keruntuhan yang dipakai dalam Truss Model sesuai dengan kenyataan yang sesungguhnya. Tes pembebanan dilakukan di laboratorium struktur jurusan Teknik Sipil FTSP ITS.

\section{MATERIAL DAN PENGUJIAN 4.1. Penulangan}

Dari hasil uji tarik tulangan diketahui tulangan tarik longitudinal mempunyai tegangan leleh $f_{y}$ sebesar $470 \mathrm{MPa}$, sedangkan tulangan geser mempunyai tegangan leleh $\mathrm{f}_{\mathrm{y}}$ sebesar $320 \mathrm{MPa}$.

\subsection{Beton}

Pengujian benda uji silinder dilakukan bersamaan dengan uji beban balok yang pada umumnya dilakukan setelah balok berumur minimal 4 minggu. Hasil tes tekan menunjukkan bahwa kekuatan tekan bervariasi antara $25 \mathrm{MPa}$ hingga $39 \mathrm{MPa}$.

Adapun model test yang dipakai untuk uji beban dapat dilihat pada Gambar 2. Model tersebut dipilih untuk mendapatkan gaya geser yang tetap pada daerah shear span. Dalam studi ini yang dipakai sebagai variabel dalam uji beban adalah : 
a. Luas tulangan tarik $\left(A_{s}\right)$

b. Persentase tulangan geser $\left(q_{v}\right)$

c. Rasio a/d

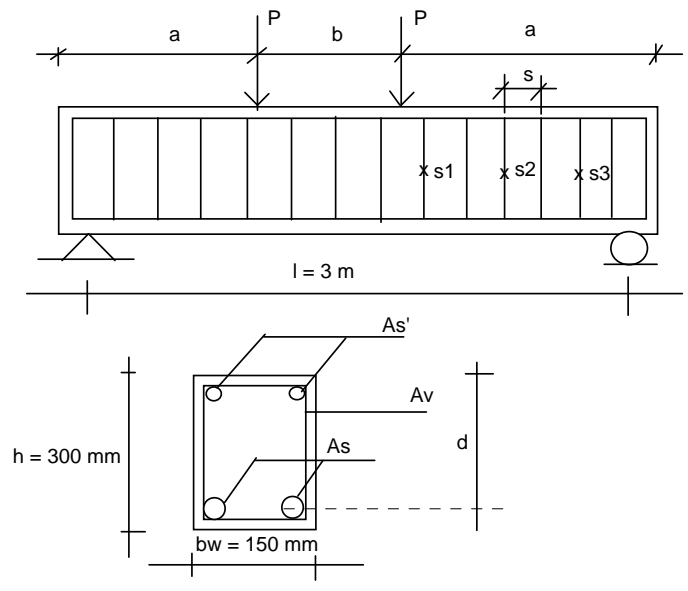

Gambar 2. Model Tes Pembebanan Balok \& Penempatan Strain Gage

Tabel 5. Data Balok Beton Bertulang

\begin{tabular}{|c|c|c|c|c|c|c|c|}
\hline Balok & $\mathbf{d}(\mathbf{m m})$ & $\mathbf{a} / \mathbf{d}$ & $\begin{array}{c}\mathbf{f}_{\mathbf{c}} \\
\mathbf{M P a}\end{array}$ & $\mathbf{A}_{\mathbf{s}}\left(\mathbf{m m}^{2}\right)$ & $\mathbf{A}_{\mathbf{s}}{ }^{\prime}\left(\mathbf{m m}^{2}\right)$ & $\rho(\mathbf{\%})$ & $\mathbf{q}_{\mathbf{v}}=\left(\mathbf{A}_{\mathbf{v}} \mathbf{f}_{\mathbf{y}}\right) /\left(\mathbf{b}_{\mathbf{w}} \mathbf{s} \mathbf{f}_{\mathbf{c}}\right)$ \\
\hline \hline B-1 & 247 & 3,44 & 25 & $1386(4 \mathrm{D} 21)$ & $693(2 \mathrm{D} 21)$ & 4,00 & $0,021(\phi 5-200)$ \\
\hline B-2 & 247 & 3,44 & 25 & $2079(6 \mathrm{D} 21)$ & $1039(3 \mathrm{D} 21)$ & 6,00 & $0,042(\phi 5-100)$ \\
\hline B-3 & 245 & 3,47 & 25 & $1733(5 \mathrm{D} 21)$ & $1039(3 \mathrm{D} 21)$ & 5,00 & $0,041(\phi 7-200)$ \\
\hline B-4 & 234 & 3,63 & 25 & $2079(6 \mathrm{D} 21)$ & $1386(4 \mathrm{D} 21)$ & 6,00 & $0,055(\phi 7-150)$ \\
\hline B-5 & 233 & 3,65 & 25 & $2079(6 \mathrm{D} 21)$ & $1386(4 \mathrm{D} 21)$ & 6,00 & $0,068(\phi 9-200)$ \\
\hline B-6 & 261 & 4,00 & 39 & $1039(3 \mathrm{D} 21)$ & $60(2 \phi 6)$ & 2,66 & $0,010(\phi 5-200)$ \\
\hline B-7 & 269 & 4,50 & 30 & $1039(3 \mathrm{D} 21)$ & $60(2 \phi 6)$ & 2,66 & 0,000 \\
\hline
\end{tabular}

$\rho=$ persentase tulangan tarik $=A_{s} /\left(b_{w} d\right)$

Dimensi balok dibuat tetap (150 mm × 300 $\mathrm{mm})$, sementara besarnya perbandingan antara a dan d (a/d) berkisar antara 3,44 s/d 4,50 (lihat Gambar 2). Data balok yang diuji dapat dilihat pada Tabel 5. Persentase tulangan tarik $(\rho)$ dari balok dibuat cukup besar untuk menghindari keruntuhan akibat momen lentur. Balok dibebani sampai terjadi keruntuhan geser dengan cara menaikkan beban $P$ secara bertahap menggunakan pembebanan secara monotonik. Setiap kenaikan beban $10 \mathrm{KN}$, perambatan retak diamati dan ditandai.

Untuk mengetahui perubahan yang terjadi pada tulangan geser selama dibebani, dipasang strain gage pada 3 balok (B-3, B-4 dan B-5). Hal ini dilakukan untuk mengetahui kebenaran asumsi beberapa Truss Model (Collins dkk dan Hardjasaputra) yang memakai regangan pada tulangan geser sebagai kriteria keruntuhan.
Posisi strain gage yang dipasang dapat dilihat pada Gambar 2. Dial gage dipasang pada tengah bentang untuk memonitor lendutan yang terjadi

\section{HASIL YANG DIPEROLEH}

5.1. Truss Model dan data tes geser yang ada dalam literatur

Cara ini dilakukan dengan membandingkan kekuatan geser berdasarkan keempat Truss Model dengan hasil tes geser yang didapat dari survey literatur seperti terlihat pada Gambar 3. Hasil tes geser tersebut berasal dari percobaan geser yang telah dilakukan di Denmark, Jerman dan Inggris seperti dilaporkan oleh Placas dan Regan (1971). Data tes geser tersebut mencakup variabel yang bervariasi untuk mutu beton, mutu tulangan, jumlah tulangan lentur dan geser, shear-span depth ratio dan ukuran balok.

Gambar 3 menunjukkan bahwa untuk $\mathrm{q}_{\mathrm{v}}<0,1$, Truss Model usulan Nielsen menghasilkan 
prediksi kekuatan geser yang merupakan rata-rata dari hasil percobaan dan bukannya batas bawah seperti yang diasumsikan Nielsen untuk menurunkan perumusan geser yaitu memakai lower bound analysis. Untuk mengatasi kelemahan ini, Nielsen membatasi nilai sudut batang tekan (cot $\theta<2,5)$ untuk nilai gaya geser yang rendah. Pembatasan ini tidak didukung dengan alasan yang rasional dan hanya untuk menyesuaikan dengan hasil percobaan.

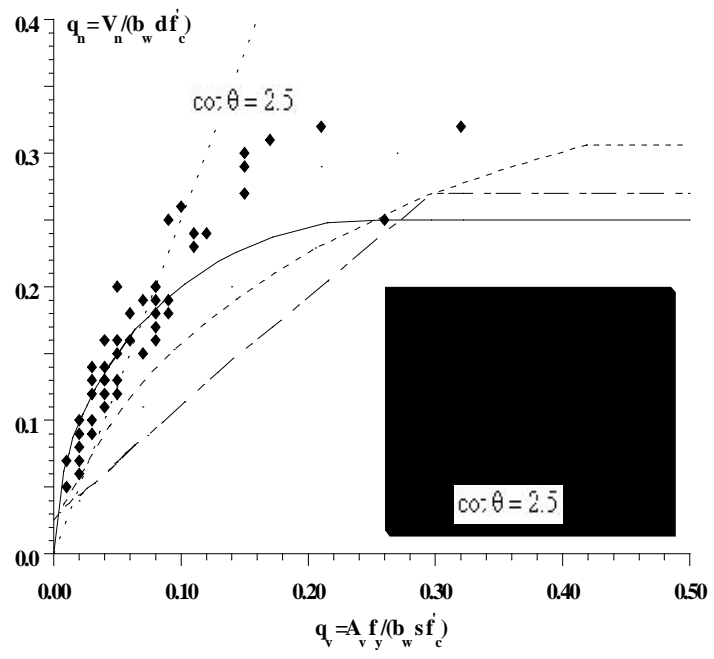

Gambar 3. Perbandingan antara Truss Model dengan Hasil Tes

Kelemahan model ini terjadi karena asumsi keruntuhan yang dipakai (batang tekan runtuh bersamaan lelehnya tulangan geser) tidak terjadi, kecuali untuk jumlah tertentu tulangan geser yaitu $\mathrm{q}_{\mathrm{v}}=\mathrm{q}_{\mathrm{vmax}}= \pm 0,25$ (versi Nielsen). Sedangkan untuk nilai $\mathrm{q}_{\mathrm{v}}<\mathrm{q}_{\mathrm{vmax}}$, tulangan geser akan meleleh sebelum batang tekan runtuh dan untuk $\mathrm{q}_{\mathrm{v}}>\mathrm{q}_{\mathrm{vmax}}$, batang tekan akan runtuh sebelum tulangan geser meleleh (prinsip yang sama juga berlaku untuk balok dengan beban momen lentur yaitu adanya provisi $\left.\rho_{\max }\right)$. Hal ini akan ditunjukkan pada bagian 5.2. Kelemahan kedua dari model ini adalah untuk $\mathrm{q}_{\mathrm{v}}=0$ (balok tanpa tulangan geser), model ini menghasilkan kekuatan geser $=0$. $\mathrm{Hal}$ ini bertentangan dengan hasil percobaan yang menunjukkan bahwa balok tanpa tulangan geser mempunyai kekuatan geser yang cukup berarti $\left(\mathrm{V}_{\mathrm{c}}\right)$.

Gambar 3 menunjukkan pula bahwa Truss Model usulan Collins dkk menghasilkan prediksi yang lebih baik dibandingkan dengan usulan Nielsen. Hal ini disebabkan kiteria keruntuhan geser yang dipakai jauh lebih tepat dibandingkan yang dipakai Nielsen, yaitu tulangan geser akan meleleh sebelum batang tekan runtuh untuk nilai $\mathrm{q}_{\mathrm{v}}<\mathrm{q}_{\mathrm{vmax}}= \pm 0,4$ (versi Collins dkk). Model ini juga berlaku untuk balok tanpa tulangan geser. Meskipun model ini memerlukan jarak retak sebagai data masukan, dari hasil analisa yang telah dilakukan variabel ini tidak mempunyai pengaruh yang berarti terhadap besarnya kekuatan geser.

Truss Model usulan Hardjasaputra memerlukan data masukan berupa nilai sudut retak dan nilai regangan pada tulangan geser. Dari hasil analisa yang telah dilakukan, variabel ini terbukti mempunyai pengaruh yang besar terhadap nilai kekuatan geser seperti terlihat pada Gambar 4 dan 5. Hal ini tentu saja membuka peluang bagi Hardjasaputra untuk menyesuaikan prediksi kekuatan gesernya dengan hasil percobaan. Untuk analisa perbandingan dalam Gambar 3, anggapan yang dipakai pada Truss Model usulan Hardjasaputra adalah besarnya sudut retak $35^{\circ}$ dan besarnya regangan geser pada saat keruntuhan terjadi sebesar regangan lelehnya. Nilai diatas diambil untuk mendapatkan prediksi kekuatan geser yang konservatif.

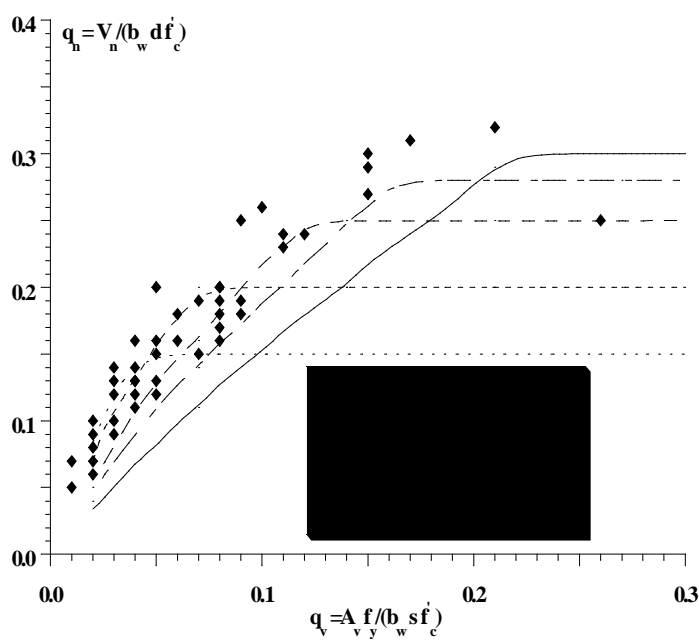

Gambar 4. Pengaruh Regangan terhadap Kekuatan Geser Hardjasaputra

Kelemahan selanjutnya dari model ini adalah tidak berlaku untuk balok dengan nilai $\mathrm{q}_{\mathrm{v}}<0,016$, termasuk balok tanpa tulangan geser. Hal ini kemungkinan besar 
disebabkan kriteria keruntuhan geser yang dipakai yaitu keruntuhan geser tergantung pada besarnya regangan pada tulangan geser hanya berlaku untuk balok dengan jumlah tulangan geser yang agak banyak $\left(\mathrm{q}_{\mathrm{v}}>\right.$ 0,016).

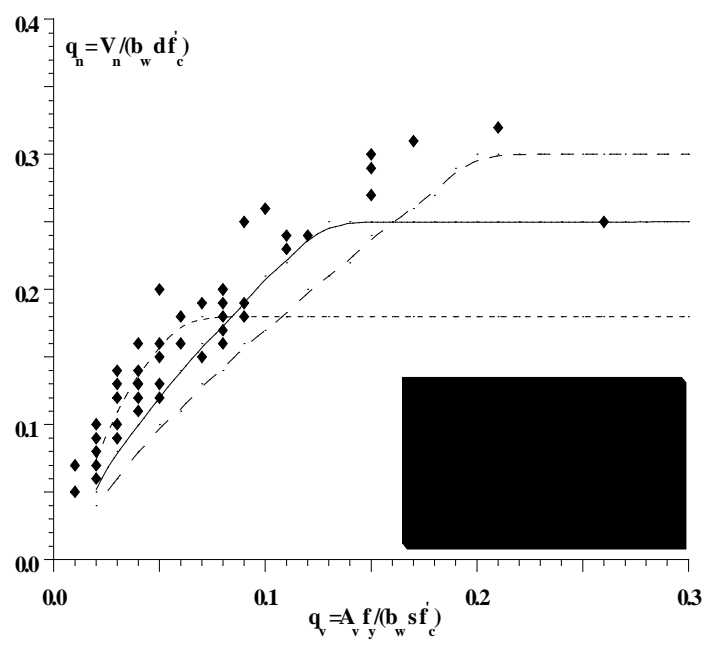

Gambar 5. Pengaruh Sudut Retak terhadap Kekuatan Geser Hardjasaputra

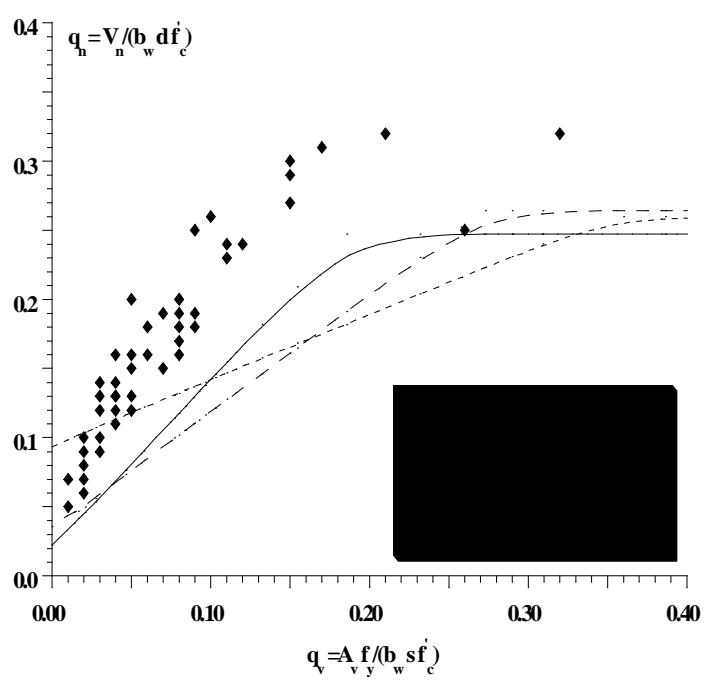

Gambar 6. Pengaruh Sudut Retak terhadap Kekuatan Geser Reineck

Untuk Truss Model usulan Reineck memerlukan data masukan berupa sudut retak. Seperti halnya pada Truss Model usulan Hardjasaputra, variabel ini mempunyai pengaruh yang relatif cukup besar terhadap nilai kekuatan geser (lihat Gambar 6). Hal ini juga membuka peluang bagi Reineck untuk menyesuaikan prediksi kekuatan geser berdasarkan model ini dengan hasil tes. Untuk keperluan perbandingan pada Gambar 3 dipakai asumsi sudut retak sebesar $45^{\circ}$.

Seperti halnya Collins dkk, model yang diusulkan Reineck berlaku baik untuk balok dengan tulangan geser maupun tanpa tulangan geser. Namun demikian bila dibandingkan dengan Truss Model lainnya, untuk balok dengan tulangan geser $\left(\mathrm{q}_{\mathrm{v}}>\right.$ 0,03 ) model ini menghasilkan prediksi kekuatan geser yang paling konservatif. Hal ini kemungkinan besar disebabkan kriteria keruntuhan yang dipakai, yaitu keruntuhan geser terjadi bila gaya geser akibat gesekan mencapai kondisi batas, hanya terjadi untuk balok tanpa atau dengan jumlah tulangan geser sedikit. Dengan bertambahnya tulangan geser, maka kriteria keruntuhan geser akan berubah.

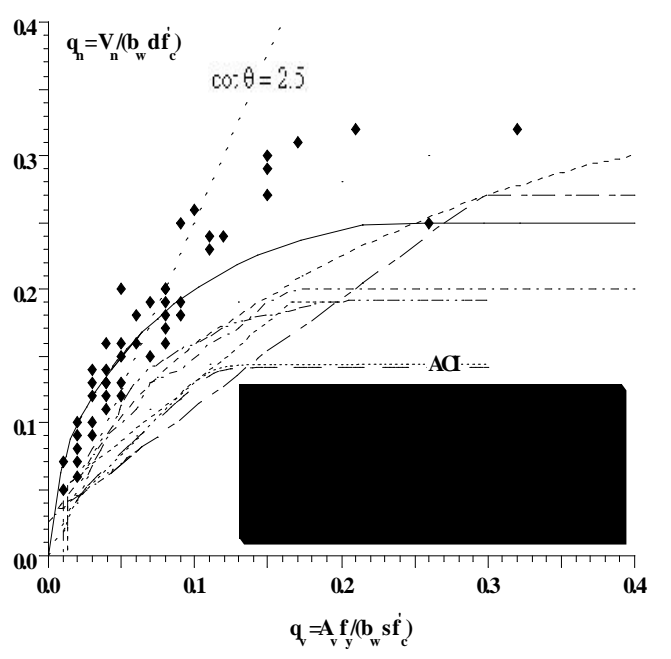

Gambar 7. Perbandingan antara Truss Model, Standar Beton dan Hasil Test

Pada Gambar 7 ditampilkan hasil perbandingan antara keempat Truss Model dengan prediksi kekuatan geser berdasarkan SNI 03-2847, AS 3600 dan Eurocode 2. Gambar 7 menunjukkan bahwa Truss Model usulan Reineck adalah yang paling konservatif dan sebaliknya Truss Model usulan Nielsen adalah yang paling tidak konservatif bila dibandingkan prediksi kekuatan geser berdasarkan ketiga standar beton diatas. Yang lebih mendekati hasil tes adalah prediksi kekuatan geser berdasarkan Truss Model usulan Collins dkk, 
Hardjasaputra, AS 3600 dan Eurocode 2. Standar beton yang menghasilkan kekuatan geser paling konservatif adalah SNI 03-2847, meskipun masih sedikit lebih baik bila dibandingkan Truss Model usulan Reineck. Berdasarkan hal ini maka Truss Model usulan Collins dkk dapat direkomendasikan sebagai alternatif perhitungan geser lentur karena relatif lebih sederhana bila dibandingkan Truss Model usulan Hardjasaputra.

\subsection{Perbandingan Truss Model dengan uji beban}

Dari hasil uji beban pada enam (6) buah balok beton bertulang didapatkan hasil seperti terlihat pada Tabel 6, sementara dari hasil pengukuran lendutan diperoleh Gambar 8. Gambar tersebut menunjukkan bahwa balok tanpa tulangan geser akan mengalami keruntuhan brittle, sementara untuk balok dengan tulangan geser akan mengalami keruntuhan ductile karena ditandai dengan lendutan yang cukup berarti sebelum balok runtuh $(7,5 \mathrm{~mm} \mathrm{~s} / \mathrm{d} 35 \mathrm{~mm})$.

Hasil pengukuran regangan tulangan geser memakai strain gage pada balok B-4 disajikan pada Gambar 9. Gambar 9 menunjukkan bahwa pada saat keruntuhan terjadi, regangan tulangan geser telah melampaui regangan lelehnya $\left(\varepsilon_{\mathrm{y}}\right)$. Hal ini sesuai dengan anggapan yang dipakai oleh Collins dkk dan Hardjasaputra yaitu pada saat keruntuhan geser terjadi, regangan pada tulangan geser akan sama atau melebihi regangan lelehnya, dengan catatan bahwa balok mempunyai persentase tulangan geser $\mathrm{q}_{\mathrm{v}}<\mathrm{q}_{\mathrm{vmax}}$. Perlu disampaikan disini bahwa tidak semua strain gage masih berfungsi ketika beban mencapai beban runtuh. Beberapa strain gage (bahkan semua) dapat mengalamai kerusakan akibat retak pada beton selama proses pengujian berlangsung, sebelum beban runtuh tercapai.

Dari pengamatan beton diantara retak (batang tekan), tidak ada tanda-tanda bahwa beton telah mencapai regangan hancurnya. Hal ini tidak bersesuaian dengan anggapan Nielsen yaitu lelehnya tulangan geser akan terjadi bersamaan runtuhnya batang tekan.
Adapun hasil perbandingan antara prediksi kekuatan geser berdasarkan keempat Truss Model dan ketiga standar beton disajikan dalam Tabel 7. Tabel 7 menunjukkan bahwa hasil perhitungan berdasarkan Truss Model lebih konservatif bila dibandingkan dengan perhitungan geser berdasarkan ketiga standar beton diatas, khususnya AS 3600 dan Eurocode 2. Namun demikian kesimpulan ini hanya diambil berdasarkan uji beban pada 7 buah balok beton dengan variabel yang sangat terbatas.

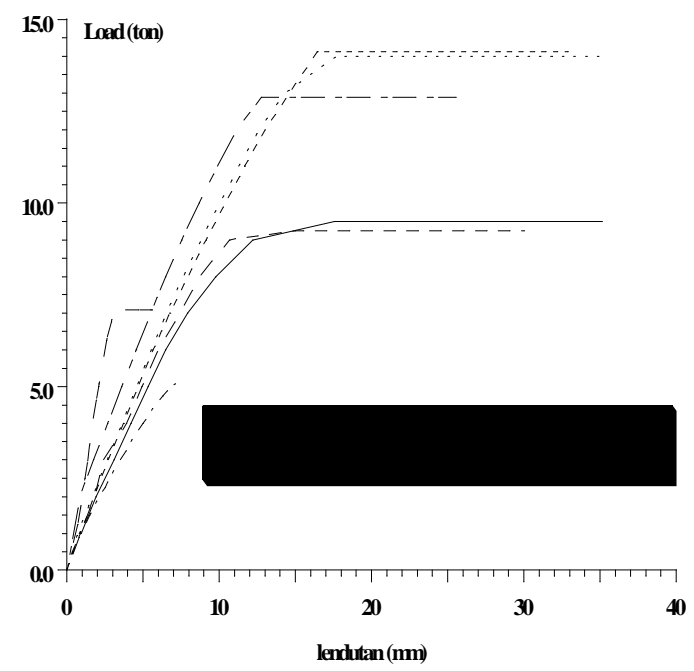

Gambar 8. Hubungan antara Beban dan Lendutan

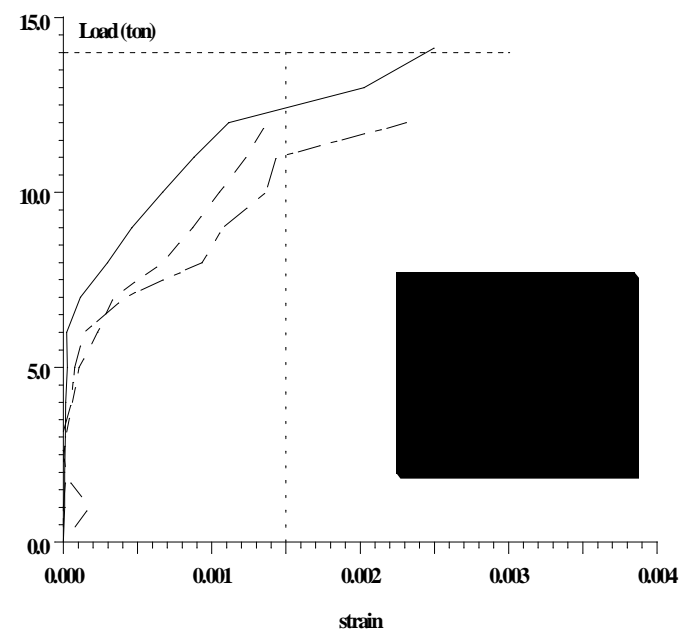

Gambar 9. Hubungan antara Regangan Tulangan Geser dengan Beban (balok B-4) 
Tabel 8. Kriteria Keruntuhan Geser

\begin{tabular}{|l|l|c|c|}
\hline \multicolumn{1}{|c|}{$\mathbf{q}_{\mathbf{v}}$} & \multicolumn{1}{c|}{ Kriteria keruntuhan } & Truss Model & Sifat \\
\hline $\mathrm{q}_{\mathrm{v}}=0$ & gaya gesekan mencapai kondisi batas & Reineck & Brittle \\
\hline $\mathrm{q}_{\mathrm{v}} \leq \mathrm{q}_{\mathrm{vmin}}$ & gaya gesekan mencapai kondisi batas & Reineck & Ductile \\
\hline $\mathrm{q}_{\mathrm{v}} \geq \mathrm{q}_{\mathrm{vmin}}$ & tulangan geser leleh sebelum batang tekan runtuh & $\begin{array}{c}\text { Collins dkk } \\
\text { Hardjasaputra }\end{array}$ & Ductile \\
\hline $\mathrm{q}_{\mathrm{v}}=\mathrm{q}_{\mathrm{vmax}}$ & tulangan geser leleh bersamaan dengan batang tekan runtuh & Nielsen & Brittle \\
\hline $\mathrm{q}_{\mathrm{v}} \geq \mathrm{q}_{\mathrm{vmax}}$ & batang tekan runtuh sebelum tulangan geser leleh & Plastic Theory & Brittle \\
\hline
\end{tabular}

\section{KESIMPULAN}

Dari penelitian yang telah dilakukan diperoleh kesimpulan sebagai berikut:

- tidak satupun Truss Model yang berlaku untuk semua kondisi jumlah tulangan geser $\left(q_{v}\right)$. Truss Model usulan Nielsen hanya berlaku untuk $\mathrm{q}_{\mathrm{v}}=\mathrm{q}_{\mathrm{vmax}}$, Truss Model usulan Reineck berlaku untuk balok tanpa tulangan atau balok dengan $\mathrm{q}_{\mathrm{v}}$ yang kecil $\left(\mathrm{q}_{\mathrm{v}}<\mathrm{q}_{\mathrm{vmin}}\right)$, sedangkan Truss Model usulan Collins dkk dan Hardjasaputra berlaku untuk $\mathrm{q}_{\mathrm{v}}>\mathrm{q}_{\mathrm{vmin}}$

- dari uji beban didapat bahwa prediksi kekuatan geser berdasarkan ketiga Model diatas (selain Nielsen) hanya mencapai rata-rata 60\%, sedangkan prediksi berdasar AS 3600 dan Eurocode 2 bisa mencapai rata-rata $80 \%$.

- dari hasil analisa geser dengan memakai Truss Model dihasilkan nilai $\mathrm{q}_{\mathrm{vmax}}$ antara 0,25 s/d 0,4, sementara berdasarkan standar beton hanya berkisar antara 0,12 s/d 0,20. Dengan demikian pemakaian Truss Model untuk perhitungan geser akan memungkinkan pemakaian balok dengan dimensi yang lebih kecil

- dari hasi tes beban diketahui bahwa Truss Model usulan Nielsen (dengan $\cot \theta \leq 2,5)$ sekalipun mempunyai prediksi kekuatan geser rata-rata sebesar $82 \%$, juga mempunyai nilai standar deviasi yang paling besar (31\%) dibandingkan dengan yang lainnya

- berdasarkan hasil tersebut diatas maka Truss Model yang direkomendasikan sebagai alternatif perhitungan geser adalah Truss Model usulan Collins dkk. Hal ini didasarkan pada hasil analisa geser dimana model ini menghasilkan prediksi yang lebih baik dibandingkan Truss Model usulan Nielsen dan Reineck, serta perumusannya jauh lebih sederhana bila dibandingkan dengan Truss Model usulan Hardjasaputra. Selain itu model ini berlaku juga untuk balok tanpa tulangan geser, meskipun cenderung over-konservatif

\section{DAFTAR ACUAN}

AASHTO LRFD. 2004. Bridge Design Specifications and Commentary 3rd Edition. American Association of State Highway Transportation Officials, Washington, D.C., 1264 pp.

ACl Committee 318. 1999. Building Code Requirements for Structural Concrete (ACl 318-99). American Concrete Institute, Farmington Hills, Mich., 430 pp.

Bentz, E.C.; Vecchio, F.J.; Collins, M.P. 2006. Simplified Modified Compression Field Theory for Calculating Shear Strength of Reinforced Concrete Elements. ACI Structural Journal, V. 103, No. 4, July-August, pp. 614-624.

CSA Committee A23.3. 2004. Design of Concrete Structures (CSA A23.3-04). Canadian Standards Association, Mississauga, 214 pp.

Collins, M.P.; Mitchell, D.; Adebar, P.; Vecchio, F.J. 1996. A General Shear Design Model. ACl Sructural Journal, V. 93, No. 1, January-February, pp. 36-45.

Commission of the European Communities. 1989. Eurocode No. 2: Design of Concrete Structure, Part 1: General Rules and Rules for Buildings, Oct.

Hardjasaputra, H. 1987. Consideration of the State of Strain in the Shear Design of Reinforced concrete and Prestressed 
Concrete Girders (in German), Dr.-Ing. thesis, University of Stuttgart, pp. 1-173.

Nielsen, M.P.; Braestrup, M.W.; Jensen, B.C.; Bach, F. 1978. Concrete Plasticity: Beam Shear-Shear in Joints-Punching Shear. Special Publication, Danish Society for Structural Science and Engineering, Copenhagen, pp. 1-129.

Placas, A. and Regan, P.E. 1971. Shear Failure of Reinforced Concrete Beams. Journal ACl, V. 68, Oct., pp. 763-773.

Reineck, K.H. 1991. Modeling of Member with Transverse Reinforcement. IABSE Colloquium Stuttgart 1991, IABSE Report, V. 62, Zurich, pp. 481-488.

SNI 03-2847. 2002. Tata Cara Perhitungan Struktur Beton untuk Bangunan Gedung.
Somo, S. and Hong, H.P. 2006. Modeling error analysis of shear predicting models for RC beams. Structural Safety, V. 28, pp. 217-230

Standard Association of Australia. 2001. Australian Standard for Concrete Structures, (AS 3600-2001). North Sydney, $176 \mathrm{pp}$.

Bentz, E.C.; Vecchio, F.J.; Collins, M.P. 2006. Simplified Modified Compression Field Theory for Calculating Shear Strength of Reinforced Concrete Elements. ACI Structural Journal, V. 103, No. 4, July-August, pp. 614-624.

von Ramin, M. and Matamoros, A.B. 2006. Shear Strength of Reinforced Concrete Members Subjected to Monotonic Loads. $\mathrm{ACl}$ Structural Journal, V. 103, No. 1, January-February, pp. 83-92. 